\title{
Pesticide Residues
}

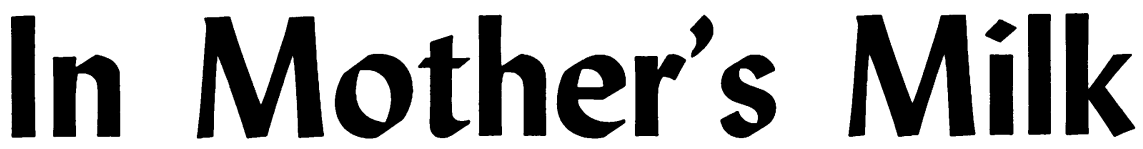

And Human Fat
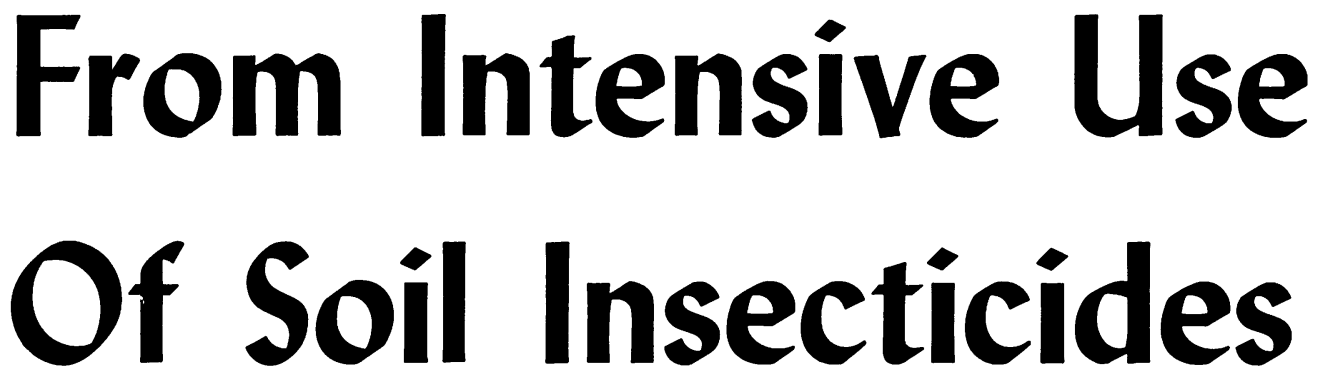

ANTHONY A. LARSEN, M.D., D.P.H., C.R.C.P (C), JAMES M. ROBINSON, M.D., D.P.H., C.R.C.P. (C), NICHOLAS SCHMITT, M.D., D.P.H., C.R.C.P. (C), and LEONARD W. HOLE, B. COMM., M.P.H.

THE PRESENCE of pesticide residues in both 1 food and water is of increasing concern because continued ingestion of these toxic compounds, even in minute quantities, may cause chronic conditions in man which are presently unrecognized. Extensive routine surveillance programs have been carried out in many countries, particularly in the United States, to determine the level of residues normally contained in almost every commercial food product. Maximum permitted pesticide residue levels have been set for most foods; those that do not meet the standards are removed from the market, usually by Federal authorities.
The authors are with the Health Branch of the Department of Health Services and Hospital Insurance, British Columbia, Canada. Dr. Larsen is director, Division of Epidemiology; Mr. Hole is senior research officer, Division of Vital Statistics; Dr. Schmitt is director, West Kootenay Health Unit; and Dr. Robinson was director of the Northern Interior Health Unit at the time of this study. Tearsheet requests to Dr. Anthony A. Larsen, Department of Health Services and Hospital Insurance, Parliament Bldgs., Victoria, British Columbia, Canada. 
During a routine survey a few years ago, the Canadian Federal Food and Drug Directorate found that a sample of milk obtained from a dairy in Grand Forks, B.C., contained traces of the pesticide dieldrin. Further investigation revealed that the cream in milk being shipped to this dairy from one farmer contained slightly more than $0.5 \mathrm{ppm}$ of dieldrin, and from another farmer the cream contained $0.2 \mathrm{ppm}$ of dieldrin. Since Canadian regulations prohibit the sale of milk containing even a trace of pesticide, the two farmers were ordered to stop selling their milk.

\section{Animal Studies}

The findings led to further studies in conjunction with the British Columbia Department of Agriculture. Samples of meat taken from locally slaughtered cattle and hogs were examined, and levels of dieldrin above those permitted by regulations of the Food and Drug Directorate were found in the fat of some cattle and hogs being sold for slaughter at a large local feedlot. Therefore, the owners of these animals were also prohibited from offering them for sale. The affected cattle and hogs were purchased jointly by the Federal and Provincial governments for research purposes so that the farmers could buy new, uncontaminated stock.

Because of favorable climatic and soil conditions, potatoes have been widely grown commercially for many years in the Grand Forks area. In 1953 the pesticides aldrin and heptachlor were introduced for the control of soil insects, mainly wireworms and tuber flea beetles, which attacked these crops. These pesticides were freely used until warnings about their potential toxicity, if applied excessively, were issued by the British Columbia Department of Agriculture. In 1961 farmers were advised of the hazard to animals that could follow indiscriminate use of aldrin and heptachlor.

There is considerable evidence (1-3) that root crops, as well as forage and possibly grain, grown on soil treated as long as 10 years previously with aldrin will take up residues of this chemical. It also has been reported $(4,5)$ that if certain pesticides are present, even in trace amounts, in the feed of lactating cows or beef cattle they will be concentrated in the cream or animal fat, and the leve! in either may well be much higher than that found in the feed itself. When taken up by plant tissues or ingested, aldrin metabolizes to
Table 1. Characteristics of study and control groups, by sex, age, and years of residence in area, Grand Forks and Prince George, B.C.

\begin{tabular}{l|c|c|c|c}
\hline $\begin{array}{c}\text { Specimens } \\
\text { and area }\end{array}$ & Male & Female & $\begin{array}{c}\text { Median } \\
\text { age }\end{array}$ & $\begin{array}{c}\text { Median } \\
\text { years of } \\
\text { residence }\end{array}$ \\
\hline $\begin{array}{c}\text { Mother's milk: } \\
\text { Grand Forks . }\end{array}$ & $\ldots$ & 15 & 22 & 3.5 \\
$\begin{array}{c}\text { Prince George } \\
\text { Human fat: }\end{array}$ & $\ldots$ & 16 & 25 & 3.5 \\
$\begin{array}{c}\text { Grand Forks . } \\
\text { Prince George }\end{array}$ & 7 & 10 & 36.5 & 8 \\
\hline
\end{tabular}

dieldrin and heptachlor to heptachlor epoxide, and these metabolites appear in the milk or are stored in the body fat of both animals and man.

At first it was believed that the milk had been contaminated because the cattle had been fed cull potatoes which contained small amounts of dieldrin, and that the problem could be eliminated by replacing the cattle and eliminating the potatoes from the diet of the new herds. After a few months, dieldrin was again detected in cream separated from milk from three farms in the Grand Forks area. The levels of dieldrin ranged from $\mathbf{0 . 3}$ to $0.6 \mathrm{ppm}$. All the farmers concerned denied having fed potatoes to their cattle. Subsequent investigation showed that the forage and possibly the grain they had been using contained traces of dieldrin or heptachlor epoxide.

From the experience gained through the studies conducted on the original herds which had been purchased by the Federal and Provincial governments it was known that it was possible to reduce the dieldrin residual in the cream to undetectable levels within a few months by use of uncontaminated feed. Therefore, the newly affected herds were not purchased by the two governments; instead, the farmers were given financial assistance to permit them to buy pesticide-free feed for their cattle. Although the Federal Food and Drug Directorate again took action to stop the sale of whole milk from these farms, the sale of skim milk was permitted.

\section{Studies in People}

The residents of Grand Forks and the surrounding countryside eat a substantial amount of locally produced food, particularly meat, dairy products, and vegetables. Therefore, exposure to aldrin and heptachlor was unlikely to be restricted to animals-the residents of this community also 
could have accumulated detectable amounts of these pesticides in their tissues. Durham and coworkers (6) were unable to detect any important difference in DDA excretion in urine, even with heavy environmental exposure when compared with the general population. However, since the situation in Grand Forks presented an excellent opportunity to investigate the extent of transmission of soil insecticides to people, we decided to extend the studies in animals to man. We collected samples of mother's milk and human fat from residents of Grand Forks and the surrounding area to see whether dieldrin and heptachlor epoxide could be detected in human specimens and, if so, whether they were present in significantly higher amounts than in other parts of the Province.

We obtained 15 specimens of mother's milk from women who were in the Grand Forks hospital for delivery and the same number of specimens of human fat from patients admitted for surgery. We also collected 16 samples of mother's milk and 17 of human fat from hospitalized patients in
Prince George, a small city in central British Columbia, so that the level of pesticide residue in human tissues at Grand Forks could be compared with that found in a community where aldrin and heptachlor had not been used. It was not possible to match the study and control groups exactly because we had to obtain the specimens from patients who were hospitalized during the period of the study.

Meat, dairy products, and vegetables are, of course, also brought into both Grand Forks and Prince George from several outside sources. However, since almost all these imported foods come from the same packinghouses, dairies, and produce wholesalers, we felt that their effect on pesticide residue levels in both centers would be very similar.

The fat specimens were preserved and shipped in 80 percent alcohol, and the mother's milk was sent to the laboratory in refrigerated containers. All analyses were done at the pesticide laboratory of the British Columbia Department of Agriculture by the gas chromatography method.

Table 2. Pesticide residue in parts per million in mother's milk and human fat, Grand Forks and Prince George, B. C.

\begin{tabular}{|c|c|c|c|c|c|c|c|c|c|}
\hline \multirow{2}{*}{$\begin{array}{l}\text { Grand Forks } \\
\text { specimen No. }\end{array}$} & \multicolumn{2}{|c|}{ Dieldrin } & \multicolumn{2}{|c|}{$\begin{array}{l}\text { Heptachlor } \\
\text { epoxide }\end{array}$} & \multirow{2}{*}{$\begin{array}{c}\text { Prince } \\
\text { George } \\
\text { specimen } \\
\text { No. }\end{array}$} & \multicolumn{2}{|c|}{ Dieldrin } & \multicolumn{2}{|c|}{ Heptachlor epoxide } \\
\hline & Milk & Fat & Milk & Fat & & Milk & Fat & Milk & Fat \\
\hline 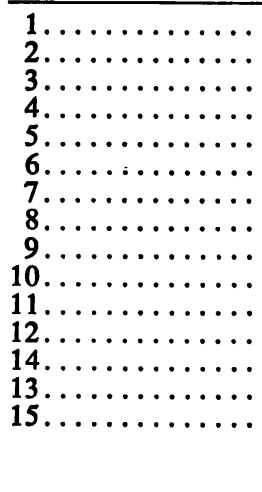 & $\begin{array}{l}\cdots \\
\cdots \\
\cdots \\
\cdots \\
\cdots \\
\cdots \\
\cdots \\
\cdots \\
\cdots \\
0.00 \\
\cdots \\
\cdots \\
\cdots\end{array}$ & $\begin{array}{l}0.018 \\
1.810 \\
\ldots \ldots \\
.320 \\
.520 \\
.024 \\
.230 \\
\ldots \ldots \\
.004 \\
.362 \\
.276 \\
.240\end{array}$ & 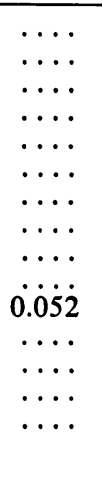 & $\begin{array}{l}0.014 \\
.518 \\
\ldots \ldots \\
.30 \\
.350 \\
.008 \\
.120 \\
\ldots \ldots \\
.023 \\
.39 \dot{ } \\
.042 \\
.166\end{array}$ & $\begin{array}{r}1 \\
2 \\
2 \\
4 \\
5 \\
6 \\
7 \\
8 \\
9 \\
10 \\
11 \\
12 \\
13 \\
14 \\
15 \\
16 \\
17\end{array}$ & $\begin{array}{c}\ldots \\
\cdots \\
\cdots \\
\cdots \\
\cdots \\
\cdots \\
0.013 \\
\ldots \\
\cdots \\
\cdots \\
\cdots \\
\cdots \\
\cdots \\
\cdots\end{array}$ & $\begin{array}{l}\ldots \\
\ldots \\
\cdots \\
\ldots \\
\ldots \\
\cdots \\
\cdots \\
\ldots \\
\cdots \\
\ldots \\
\ldots \\
\ldots \\
\cdots \\
\cdots \\
0.087\end{array}$ & $\begin{array}{l}\ldots \\
\ldots \\
\ldots \\
\ldots \\
\ldots \\
\ldots \\
\ldots \\
\ldots \\
\ldots \\
\ldots \\
\ldots \\
\ldots \\
\ldots \\
\ldots \\
\ldots \\
0\end{array}$ & $\begin{array}{c}0.136 \\
\ldots \\
\ldots \\
\ldots \\
\ldots \\
\ldots \\
\ldots \\
\ldots \\
\ldots \\
.121 \\
\ldots \\
\ldots \\
\ldots \\
\ldots\end{array}$ \\
\hline
\end{tabular}

Table 3. Presence or absence of pesticide residue in mother's milk and human fat, Grand Forks and Prince George, B. C.

\begin{tabular}{|c|c|c|c|c|c|c|c|c|}
\hline \multirow{3}{*}{ Residue found } & \multicolumn{4}{|c|}{ Dieldrin } & \multicolumn{4}{|c|}{ Heptachlor epoxide } \\
\hline & \multicolumn{2}{|c|}{$\begin{array}{l}\text { Grand } \\
\text { rorks }\end{array}$} & \multicolumn{2}{|c|}{$\begin{array}{l}\text { Prince } \\
\text { George }\end{array}$} & \multicolumn{2}{|c|}{$\begin{array}{l}\text { Grand } \\
\text { Forks }\end{array}$} & \multicolumn{2}{|c|}{$\begin{array}{l}\text { Prince } \\
\text { George }\end{array}$} \\
\hline & Milk & Fat & Milk & Fat & Milk & Fat & Milk & Fat \\
\hline $\begin{array}{l}\text { Yes }(>0.004 \mathrm{ppm}) \\
\text { No }(<0.004 \mathrm{ppm})\end{array}$ & $\begin{array}{r}1 \\
14\end{array}$ & $\begin{array}{l}9 \\
6\end{array}$ & $\begin{array}{r}1 \\
15\end{array}$ & $\begin{array}{r}1 \\
16\end{array}$ & $\begin{array}{r}1 \\
14\end{array}$ & $\begin{array}{l}9 \\
6\end{array}$ & $\begin{array}{r}0 \\
16\end{array}$ & $\begin{array}{r}2 \\
15\end{array}$ \\
\hline Total & 15 & 15 & 16 & 17 & 15 & 15 & 16 & 17 \\
\hline
\end{tabular}


The characteristics of the study and control groups-sex, median age, and median length of residence in the area under study-are shown in table 1.

Table 2 shows the levels of dieldrin and heptachlor epoxide found in the samples of mother's milk and human fat, and table 3 shows the presence or absence of pesticide residues in these samples.

\section{Discussion}

Selection of study and control groups. We belive that the specimens examined were representative of both mother's milk and human fat in the two areas. The mothers were selected consecutively from women admitted to the two hospitals for delivery on the basis of their willingness to participate in the study and the availability of sufficient milk for analysis. Fat specimens were obtained from a consecutive series of patients admitted for surgical procedures of a type which permitted a suitable sample to be obtained.

Both the study and control groups from whom mother's milk was obtained were remarkably similar in the characteristics for which information was available-median age and median years of residence in the area (table 1 ). The two groups who provided the fat samples did, however, vary in sex distribution, median age, and median length of residence in the two areas.

The differences in sex distribution and median age were small, and in other studies $(7,8)$ such variations were found not to affect low levels of chlorinated hydrocarbon storage in human tissues. Other studies $(9,10)$ have also shown that the storage of pesticide residue in man is proportionate to dosage and reaches an equilibrium in about a year despite continued intake.

The longer period of exposure of one of the groups providing fat tissue should not, therefore, affect the relative levels of residue found in both the study and control groups.

Statistical analysis. Pesticide residue was not detectable in amounts of less than $0.004 \mathrm{ppm}$, owing to limitations of the analytic procedure. When the results were tabulated according to whether residue was detected or not (table 3 ) and the data tested for significance, using the exact probability method developed by Mainland and co-workers (11), there was no significant association between the presence of pesticide residue in mother's milk and place of residence. There was, however, an association between the residue levels of both dieldrin and heptachlor epoxide found in the human fat samples and the locations from which they were obtained. This association is significant beyond the 0.001 level.

We had hoped to be able to show an association between the use of locally produced food and pesticide residue levels, but this proved impossible. Both the study and control groups were asked, by questionnaire, about their use of local and imported foods. An individual analysis of the completed questionnaires showed that a number of persons in the study group ate only locally produced meat, dairy products, and potatoes. We considered these foods most likely to rontain significant levels of dieldrin and heptachlor epoxide. However, none of the study group limited their diets to imported brands of these three foods. Conversely, in the control group no one ate locally produced varieties of these three foods exclusively.

Our failure to find more than three specimens of mother's milk containing detectable dieldrin and heptachlor epoxide residue could have been due to faulty technique. It could also be an indication that these two pesticides do not concentrate in mother's milk to the degree that they do in human fat. Egan and associates (12) found that the levels of dieldrin residue in 19 samples of mother's milk studied in the United Kingdom were on the average 30 times less than the corresponding levels in human fat. This, he felt, suggested that there was a distribution equilibrium in the fat phase of the body.

Two additional samples of mother's milk from the Grand Forks hospital analyzed at the Ottawa laboratory of the Federal Food and Drug Directorate showed dieldrin levels of 0.040 and 0.004 ppm and heptachlor epoxide levels of 0.055 and $0.003 \mathrm{ppm}$. These levels are in accord with those reported by our laboratory and by Egan, who found levels ranging from 0.009 to $0.037 \mathrm{ppm}$ in his investigations in England. This phase of our study is being continued and will be reported later.

\section{REFERENCES}

(1) Steward, D. K. R., Chisholm, D., and Fox, C. J. S.: Insecticide residues in potatoes and soil after consecutive soil treatments of aldrin and heptachlor. Canad J Plant Sci 45: 72-78 (1965).

(2) Wilkinson, A. T. S., Finlayson, D.G., and Morley, 
H. V.: Toxic residues in soil nine years after treatment with aldrin and heptachlor. Science 143: 681-682 (1965).

(3) Lichtenstein, E. P., and Schulz, K. R.: Residues of aldrin and heptachlor in soils and their translocation into various crops. J Agr Food Chem: 13: 57-60 (1965).

(4) Bruce, U. N., Link, R. P., and Decker, G. C.: Storage of heptachlor-epoxide in the body fat and its excretion in milk of dairy cows fed heptachlor in their diets. J Agr Food Chem 13: 63-67 (1965).

(5) Gannon, N., Link, R. P., and Decker, G. C.: Pesticide residues in meat and milk: storage of dieldrin in tissues and its excretion in milk of dairy cows fed dieldrin in their diet. J Agr Food Chem 17: 824-826 (1959).

(6) Durham, W. F., Armstrong, J. F., and Quinby, G. E.: DDA excretion levels. Arch Environ Health (Chicago) 11: 76-79, July 1965.

(7) Robinson, J., et al.: Organo-chlorine insecticide content of human adipose tissue in southeastern
England. Brit J Industr Med 22: 220-229 (1965).

(8) Hayes, W. J., Jr., et al.: Storage of DDT and DDE in people with different degrees of exposure to DDT. Arch Indust Health 18: 398-406, November 1958.

(9) Hayes, W. J., Jr., Durham, W. F., and Cueto, C., Jr.: The effect of known repeated oral doses of chlorophenothane (DDT) in man. JAMA 162: 890-897 (1956).

(10) Howell, D. E.: A case of DDT storage in human fat. Proc Oklahoma Acad Sci 29: 31-32 (1948).

(11) Mainland, D., Herrera, L., and Sutcliffe, M. I.: Statistical tables for use with binomial samples, contingency tests, confidence limits and sample size estimates. Department of Medical Statistics, New York University College of Medicine, 1956, p. 15 .

(12) Egan, H., Goulding, R., Roburn, J., and Tatton, J. P. G.: Organo-chlorine pesticide residues in human fat and human milk. Brit Med J 2: 66-69, July 1965.

LARSEN, ANTHONY A. (Health Branch of the Department of Health Services and Hospital Insurance, British Columbia): ROBINSON, JAMES M., SCHMITT, NICHOLAS, and HOLE, LEONARD W.: Pesticide residues in mother's milk and human fat from intensive use of soil insecticides. HSMHA Health Reports, Vol. 86, May 1971, pp. 477-481.

The unexpected discovery of significant amounts of dieldrin and heptachlor epoxide in locally produced meat and milk in Grand Forks, B.C., stimulated a study of a small sample of the adult population of this community to see whether they too might be carrying a higher than average burden of these pesticides. Samples of human fat tissue and mother's milk were obtained from 30 people in the Grand Forks area and from 33 controls living in Prince George, where pesticide use was considered minimal. These specimens were examined for the presence of organochlorine pesticide residues.

Statistical tests of the results of these examinations showed a significant increase in the levels of dieldrin and heptachlor epoxide in human fat tissue, but not in mother's milk, in the Grand Forks study area compared to the Prince George control area.

From the results of our study, we concluded that people living in a community where aldrin and heptachlor have been used freely for agricultural purposes and where a substantial proportion of the food eaten is locally produced will show a significant increase in the levels of dieldrin and heptachlor epoxide in their fatty tissues over the levels found in areas where aldrin and heptachlor have not been so widely used. 